\title{
Integrated whitefly [Bemisia tabaci (Gennadius)] management in Bt-cotton in North India: an agroecosystem-wide community-based approach
}

\author{
Vijay Kumar, Jagdev Singh Kular, Rishi Kumar, Sukhdev Singh Sidhu and \\ Pardeep Kumar Chhuneja*
}

In 2015, a whitefly epidemic devastated cotton in about $1.5 \mathrm{~m}$ ha in North India and reduced the yield level to about 35\% of average productivity in the state of Punjab. Protection of crop from sucking insect pests, including whitefly, is primarily based on insecticides. A more knowledgeintensive and multidisciplinary approach which can lead to a dramatic reduction in chemical use combined with unprecedented improvement in productivity should qualify as a worthy successor to the green revolution. Interventions include host plant resistance, robust surveillance and ETLbased decision-making, managing non-crop hosts, pest resurgence curtailment through targeted biopesticide and pesticide application, crop nutrition, and abiotic stress amelioration. Research refinements even as implementation progressed, high intensity outreach and cotton belt-wide implementation not just restored productivity, but also resulted in achieving record yields of 756, 750 and $778 \mathrm{~kg}$ lint/ha in 2016, 2017 and 2018 respectively, compared with $197 \mathrm{~kg}$ lint/ha in $2015 \mathrm{in}$ Punjab, and pesticide savings during these years over 2015 were INR 2589/ha, 2808/ha and 3060/ha respectively. The success story and its modus operandi have implications for "new agriculture', which needs to be disseminated and debated widely.

Keywords: Agroecosystem, Bemisia tabaci, Bt-cotton, community-based approach.

THE whitefly, Bemisia tabaci (Gennadius) can infest more than 1000 plant species, including major crops such as cotton, sweet potato, cassava, tomato, cucumber, brinjal, cabbage, etc. and transmits over 300 plant pathogenic viruses, including cotton leaf curl virus, tomato yellow leaf curl virus, cassava mosaic virus and cassava brown streak virus ${ }^{1}$. Wide host adaptability, virus transmission capability, potential for rapid evolution (a complex of 39 cryptic species) and invasiveness have rendered the management of whitefly difficult ${ }^{2}$. Importantly, it has tremendous potential to develop resistance to insecticides ${ }^{3}$. Whiteflies were first reported in 1889 on tobacco in Greece $^{4}$. However, their incidence on different crops was sporadic till the $1980 \mathrm{~s}$. In the last three decades, however, whiteflies have gained the status of a key pest with a

Vijay Kumar, Jagdev Singh Kular and Pardeep Kumar Chhuneja are in the Punjab Agricultural University, Ludhiana 141 004, India; Rishi Kumar is in the ICAR-Central Institute of Cotton Research, Sirsa 125 055, India; Sukhdev Singh Sidhu is in the Department of Agriculture (Punjab), Mohali 160 055, India.

*For correspondence. (e-mail: pkchhuneja@pau.edu) global footprint. The adults are tiny ( $1 \mathrm{~mm}$ long) insects that feed on phloem sap. The female whitefly has been reported to lay 18.10-86.0 eggs on different cotton genotypes under Indian Punjab conditions 5 . The first instar nymph is the only mobile nymphal stage. The total life cycle is completed in 24-44 days. In the subtropics, about 11 generations can occur during the growing season (April-October) on cotton ${ }^{6}$. The adults can fly only to adjoining plants but can be transported over large distances $(2.2 \mathrm{~km})$ by wind ${ }^{7}$.

With respect to cotton grown in northwestern India, the whiteflies had a regular but manageable presence during the last decade. In this region, as in the rest of the country, almost the entire cotton crop is Bt-cotton. Cultivation of Bollgard I (CrylAc) and Bollgard II (CrylAc and Cry $2 A b$ ) was approved in 2005 and 2009 respectively, for the northwestern zone (three states, namely Punjab, Haryana and Rajasthan). Bt-cotton provides resistance against bollworm, but protection from sucking insect pests including whiteflies is based primarily on insecticide use. Besides their sap-sucking behaviour, whiteflies precipitate yield loss by excreting honeydew that 


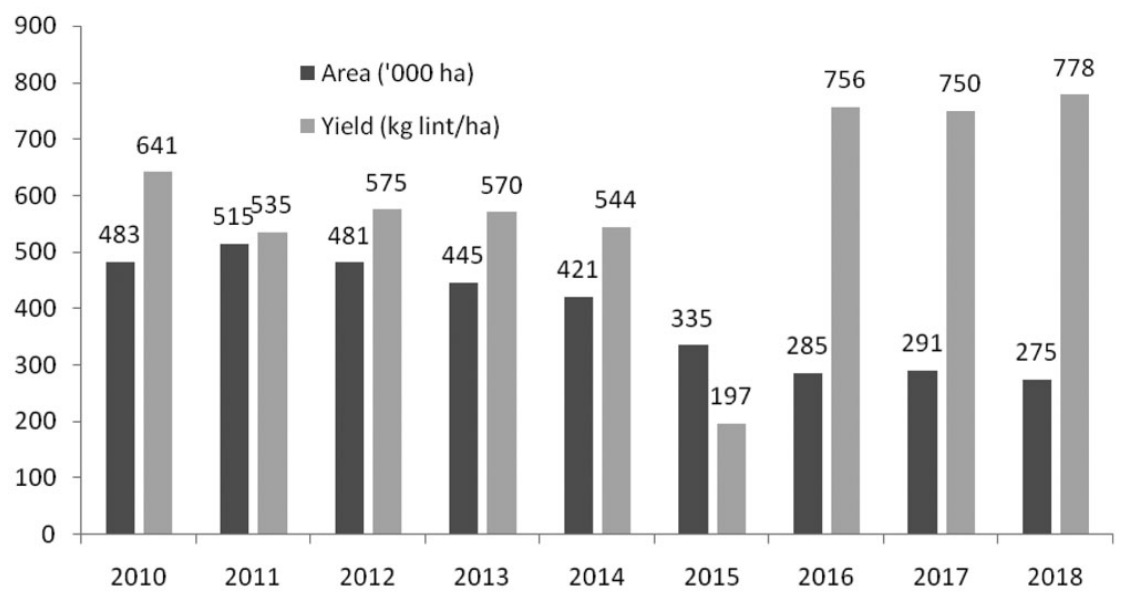

Figure 1. Cotton area and yield in Punjab, India (Source: Department of Agriculture and Farmers' Welfare, Government of Punjab).

promotes rapid growth of non-pathogenic sooty fungi (black mould) on leaves and cotton bolls. The largely pesticide-based management of whiteflies by the cottongrowers in northwestern India, factors in all these prevalent and perceived threats. It is in this backdrop that the whitefly epidemic occurred in 2015 in this region. The cotton productivity in Punjab fell substantially from the five-year (2010-14) average of $573 \mathrm{~kg}$ lint/ha to only $197 \mathrm{~kg}$ lint/ha in 2015 (Figure 1). Crop losses in Haryana and Rajasthan were no less devastating. The situation culminated in farmers' unrest. Three main inter-state rail routes in the cotton areas of Punjab were blocked during protests for almost a week. Cases of suicide as reported in the popular press were linked with crop failure ${ }^{8}$. The Government of Punjab promptly moved in by providing partial monetary compensation of INR 20,000 per ha to cotton farmers, and a proportionately worked out amount to farm labourers. This relief to cotton growers and pickers worked was INR 7360 million (equivalent to about 105 million US dollars).

Thus it is important to determine the factors responsible for whitefly outbreaks and develop strategies for its effective management in cotton. The whitefly incidence and its management strategy relate to a more or less contiguous area of about $1.5 \mathrm{~m}$ ha spread over Punjab, Haryana and Rajasthan. The present study, however is largely based on Punjab, which represents one-third to one-fifth of the total cotton-growing area in northwestern India during different years (Figure 1).

\section{Reasons for failure of cotton crop}

Owing to huge crop loss in 2015, the Governments of Haryana and Punjab set up a committee to find the reasons for such losses and strategize the future course of action. The important factors which led to the whitefly outbreak were favourable weather conditions (maximum temperature of $32-39^{\circ} \mathrm{C}$, minimum temperature of 22 $28^{\circ} \mathrm{C}$, maximum morning relative humidity of $73-91 \%$, and minimum relative humidity of $38-63 \%$ ) due to premonsoon showers in June that helped in faster multiplication of whiteflies and their appearance early in the season (June). Normally, and particularly during 2013 and 2014, whitefly population build-up on cotton in the region was observed to reach above the economic threshold (six adults per leaf) in Punjab during its peak activity months of August and September (Table 1). In 2015, the average population of whitefly adults per three leaves remained significantly higher during July to October in late-sown crops with $P$ value of $0.01-0.0009$ (Table 2). The winter of 2014-15 had been relatively mild in the cotton region and thus was conducive to the survival of whiteflies on alternative host plants during off-season. Minimum temperature during the last week of December to the first fortnight of January ranged between $3.4^{\circ} \mathrm{C}$ and $7.9^{\circ} \mathrm{C}$ in comparison to $2.3^{\circ} \mathrm{C}$ and $4.4^{\circ} \mathrm{C}$ in $2013-14$.

Another reason was delayed sowing, as cotton plantings which generally take place in the first fortnight of May (recommended time of sowing) had been delayed by about 20-25 days on large acreage. This was attributed to delayed harvest of wheat on account of unseasonal rainfall. With a larger carryover of the pest and younger, more tender cotton plants, the whiteflies made an early appearance on the crop. Most importantly, the conventionally dry month of June received frequent premonsoon showers, but heavier monsoon rainfall expected from July onwards, which might have washed away the whitefly adults, was deficient.

Cotton-growers used broad-spectrum and cheaper conventional insecticides like organophosphates (monocrotophos, acephate) and synthetic pyrethroids alone as well as in a mixture to manage whiteflies appearing early in the season, and these applications killed the natural enemies resulting into the resurgence of whiteflies ${ }^{9}$. Probably whiteflies also had resistance to insecticides, as is well 
Table 1. Incidence of whitefly adult population above economic threshold level (six adults per leaf) in cotton-growing areas of Punjab, India

\begin{tabular}{lccccrr}
\hline & \multicolumn{5}{c}{ Average population of whitefly adults per three leaves during various years } \\
\cline { 2 - 7 } Month & 2010 & 2011 & 2012 & 2013 & 2014 & 2015 \\
\hline June & 2.1 & 0.3 & 0.5 & 5.9 & 5.3 & 8.2 \\
July & 4.1 & 2.3 & 4.4 & 12.9 & 7.5 & 35.0 \\
August & 2.9 & 2.1 & 4.2 & 11.7 & 16.6 & 62.8 \\
September & 3.1 & 1.5 & 4.1 & 13.3 & 18.0 & 28.7 \\
\hline
\end{tabular}

Source: Ref. 15.

Table 2. Effect of different dates of sowing on the incidence of whiteflies in Punjab

\begin{tabular}{lcccc}
\hline & \multicolumn{4}{c}{ Average population of whitefly adults per three leaves } \\
\cline { 2 - 5 } Date of sowing & July & August & September & October \\
\hline 5 May 2015 (timely sown) & 6.4 & 9.2 & 5.8 & 2.7 \\
25 May 2015 (late sown) & 32.8 & 53.7 & 25.2 & 10.7 \\
$P$ value & 0.005 & 0.0009 & 0.004 & 0.01 \\
\hline
\end{tabular}

Data were analysed using the $t$-test; Source: Ref. 15.

recognized in the scientific literature ${ }^{3,10}$. Farmers resorted to large-scale spray of broad-spectrum insecticides. There is a disproportionately large network (about 1400 outlets) of pesticide suppliers in the cotton belt of Punjab having considerable influence on farmers' choice of insecticides. Cotton-growers used improper spray application methods (whiteflies feed from under the surface of leaves where insecticides do not reach easily) that favoured higher population build-up of whiteflies.

Whiteflies survived on alternate crops such as brinjal, cucurbits, okra, tomato, chilli, potato, etc., and weed hosts like Abutilon spp., Sida spp., Achyranthes splendens, Parthenium hysterophorus and Cotula coronopifolia and Solanum nigrum which played an important role in over-wintering/carry-over, were also part of the agroecosystem.

\section{Development of an agroecosystem-wide integrated whitefly management strategy}

Based on extensive studies carried out by research institutions in the region, including the available database on the biology and ecology of whiteflies, seasonal population dynamics on multiple hosts within the cotton agroecosystem, economic threshold level, role of $B t$-cotton cultivars, effect of crop agronomy and use of selective insecticides, a comprehensive Integrated Pest Management (IPM) strategy was developed. It included regular surveillance of whiteflies on their most preferred alternate crop hosts like brinjal and cucurbits (long melon, cucumber, summer squash) and weed hosts from February onwards and on cotton from April onwards; clean cultivation campaign during March-May to remove weeds; availability of quality inputs like seeds of recommended hybrids and insecticides; availability of canal water for timely sowing and first irrigation; awareness among farmers to apply recommended doses of fertilizers on soil test basis; ensuring plant health management by four sprays of potassium nitrate at flowering; use of non-chemical approaches (100 yellow sticky traps/ha, neem-based botanicals); application of chemical insecticides based on economic threshold level (ETL) of six whitefly adults per leaf before 10.00 am; proper spray methodology; distribution of literature among cotton-growers on the management of whiteflies; training programmes of extension functionaries, field scouts and pesticide dealers; weekly monitoring of whitefly incidence and review of management strategy, and intensive surveillance of late-sown crop.

Earlier, in the Arizona cotton system in USA, integrated control programme for whiteflies was developed, validated and implemented $^{11}$. In Punjab, the challenge for 2016 was to restore the viability of cotton as a crop in its agroecological niche comprising 1000 villages of eight districts in the state. A brief description of the initiatives and measures taken in response to this challenge is given below that form the core of this account.

\section{Robust approach to pest monitoring}

The surveillance for whitefly incidence was jointly undertaken by scientists from the Punjab Agricultural University (PAU), its Regional Research Stations, Krishi Vigyan Kendras besides scouts and regular functionaries of the State Department of Agriculture and Farmers' Welfare. The main objective was to identify the whitefly hot spots and curb the pest therein to prevent its spread. During the season, when and where the whitefly population was reported to be relatively higher, surveillance was conducted on a daily basis. Observation units were individual fields sampled from each village. Data flowed 

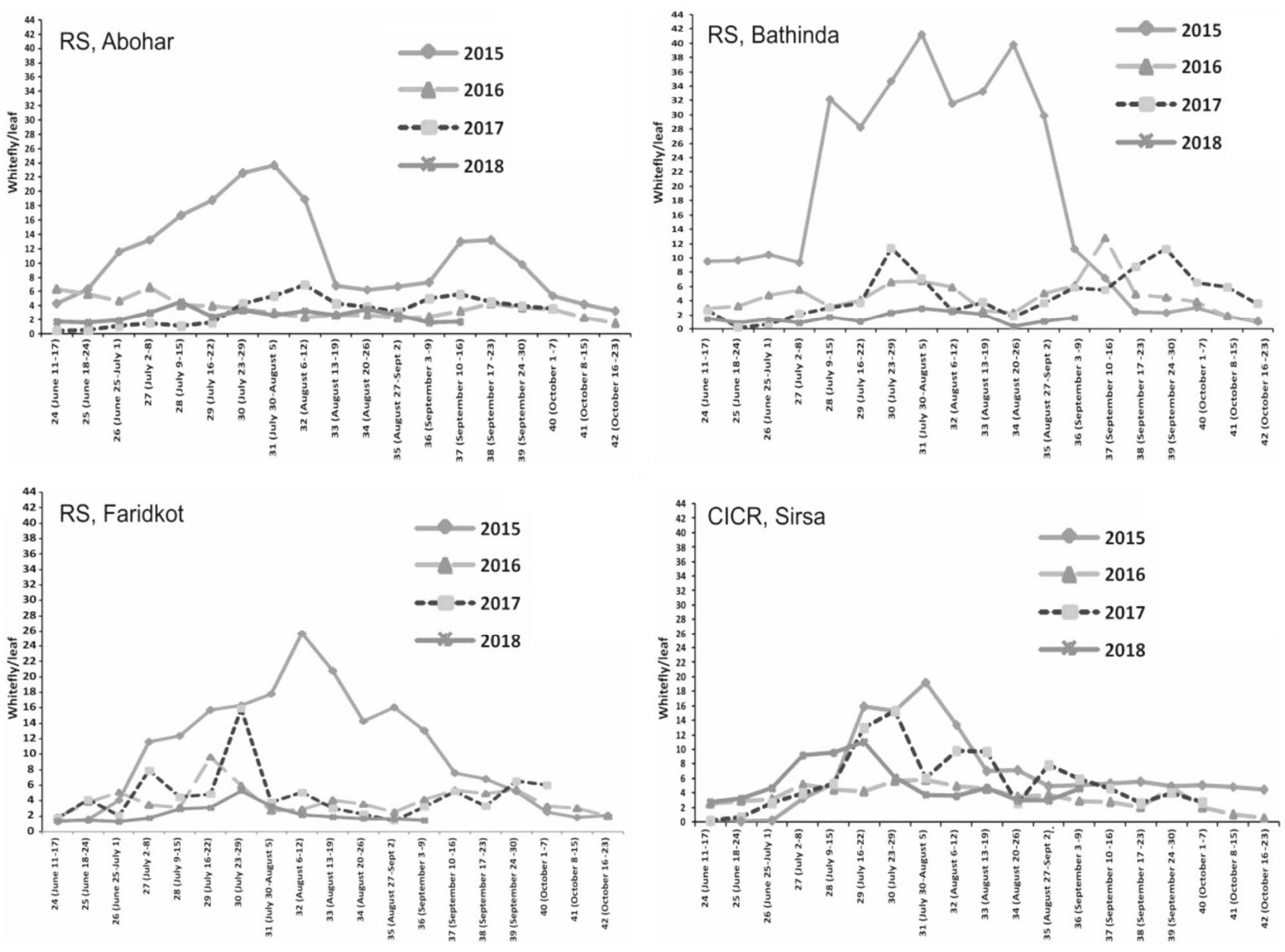

Figure 2. Comparative incidence of whiteflies on cotton during 2015, 2016, 2017 and 2018. RS, Regional stations of Punjab Agricultural University at Abohar/Bathinda/Faridkot, Punjab; CICR, Sirsa: Regional Station of Central Institute of Cotton Research at Sirsa, Haryana.

continuously into two streams - the State Department of Agriculture and the University (DAU). Exchange of information was seamless, but final corroboration would take place every week or fortnight when the teams representing both streams from each of the districts would meet under the inter-state committee ${ }^{12}$. The key observation was whitefly incidence and its build-up towards ETL of six whitefly adults per leaf before $10.00 \mathrm{am}$. Incidence levels below and above ETL had clear management implications. The strategy arrived at in the meeting was disseminated as advisories to the farmers through a series of newspaper advertisements, and also on radio and television. During 2015, untoward higher incidence of whiteflies (22-42 per leaf) was recorded in Punjab (Bathinda, Abohar and Faridkot, the major cottongrowing districts/sub-divisions), and Sirsa, Haryana (20 per leaf) due to favourable weather conditions. Owing to evolving agroecosystem-wide IPM and intensive efforts in its dissemination and ensuring its adoption, the subsequent years witnessed control, with whitefly population, in general, reeling below ETL (Figure 2).

\section{Choice of hybrids}

Uniquely, India grows $B t$-cotton hybrids approved by the Genetic Engineering Appraisal Committee (GEAC) which has biosafety as its major criterion, largely transgenic 'event'-dependent rather than agronomic performance. In 2015, the year of the whitefly epidemic, Punjab was growing more than $300 \mathrm{Bt}$-cotton hybrids. Beyond the listed hybrids, the unscrupulous practice of selling cheaper, nondescript hybrid seeds directly to the farmers prevailed during that year. Most popular hybrids did not show tolerance to whitefly. The challenge thus became twofold - to prevent the sale of nondescript hybrids and chose only the resistant ones from the GEAC approved list, for recommendation to the farmers. Sets of commercial hybrids had been evaluated at the PAU research stations during 2014 and 2015, both high whitefly incidence years, and 38 hybrids could thus be readily chosen for recommending to the farmers in 2016. The evaluation of hybrids with a focus on whiteflies and cotton leaf curl viral $(\mathrm{CLCuV})$ disease was systematized over six 
locations in the three states from 2016 onwards. The evaluation of 118 hybrids submitted by seed companies yielded 44 of them with relatively better levels of tolerance along with yield. In 2017, 60 hybrids and during 2018, 72 hybrids were chosen from 122 and 118 tested respectively. Thus, susceptible and nondescript hybrids were relegated to a negligible status. This became an important aspect of the IPM strategy in restoring the productivity of the cotton belt during 2016, 2017 and 2018.

\section{Timely sowing}

Late sowing was identified as one of the primary predisposing factors in the epidemic of 2015 (Table 2). Therefore, availability of canal water for timely sowing and first irrigation was ensured in the subsequent years.

\section{Improving coverage}

Ground activities, primarily pest monitoring, were the essence of the whitefly campaign. The Department of Agriculture and Farmers' Welfare, Government of Punjab, engaged 500 whitefly scouts for about 1000 cotton growing villages of the state ${ }^{12}$. Two villages were covered by one scout, with an exception made for larger villages which had one scout per village. Ten scouts were placed under the control of one Field Supervisor, and this ground staff was teamed-up with the regular hierarchical incumbents of the Department of Agriculture and Farmers' Welfare starting from Agricultural Sub-Inspectors finally culminating into the Chief Agriculture Officer for each district.

\section{Preventing pre-season build-up}

This included regular surveillance of whiteflies on alternate hosts like brinjal and cucurbit from February onwards and on cotton during its sowing from April onwards, and clean cultivation campaign during MarchMay to prevent the carryover of whiteflies from alternate crops and weeds to cotton ${ }^{13}$.

\section{Spray technology}

Dependence on shoulder-mounted knapsack sprayers was seen as a limitation for the effective management of whiteflies. Two tractor-mounted sprayers were designed by PAU. The auto-rotate gun sprayer provided a pressurized air blow-assisted spray capable of vigorous shake-up of foliage; even a water spray could bring down whitefly infestation, which despite being physically fragile, would otherwise escape most of the partially systemic chemicals by remaining sedentary on the lower surface of leaves. The second tractor-mounted pump was equipped with upturned nozzles hanging on flexible drop-down tubes to handle the lower leaf surface. A private company chipped in with custom hiring services. These interventions combined high capacity with low cost.

\section{Crop health route to combat whiteflies}

The plant stunting is known to result in a vicious cycle when infested with whiteflies. The infestation is able to run through the length and breadth of the plant faster if the canopy is compact, owing to stunting and reduction in internodal distance. On the contrary, faster crop growth could slow down this cycle. However, this option suffered on account of short supply of irrigation water and ill-distributed rainfall. Water stress not only led to stunting of the plants, but also reduced opportunities for nutrient application. Most farmers grew cotton alongside citrus and rice, and the latter crops received higher irrigation priority due to more assured returns. Ironically, these crops not only contributed to water stress on cotton, but also provided favourable microenvironment for whiteflies in adjoining cotton fields. Foliar application of nutrients (potassium nitrate and urea) at weekly intervals adopted en masse by the farmers, proved to be the saviour in all these situations inimical to cotton crop health.

\section{Training programmes and information initiatives}

PAU and state agencies took it upon themselves to reach out with a strong training module, to every key person that mattered for whitefly management ${ }^{12}$.

Training programmes on cotton production and protection technology were organized for extension personnel (135) from the State Department of Agriculture, scouts (1000) and pesticide dealers (2758). Training camps $(>5000)$ were organized for educating the farmers before and during the crop season at district, block and village level (Table 3). Several pamphlets $(500,000)$, latest recommendation brochures $(20,000)$, cotton wheat rotation calendars (5000), PAU's pesticide recommendation list for mandatory display at shops/outlets (7000), and identification charts for pests and their natural enemies were printed and disseminated ${ }^{13}$. It was made mandatory for all pesticide dealers in the cotton-growing belt of the State to prominently display the chart depicting the list of recommended insecticides along with their recommended dosage. Scientists and extension education specialists appeared on television and radio shows, including interactive sessions on the aspects of cotton production and protection technology. Mobile publicity vans also remained operative to create awareness.

\section{Mid-course corrections}

The IPM strategy was modified/firmed-up from time to time after examining the ground-level situation, dynamics 
GENERAL ARTICLES

Table 3. Training programmes and camps organized in the cotton belt of Punjab (2016, 2017 and 2018)

\begin{tabular}{lccc}
\hline Target group & Number of training programmes/camps per year & Number of trainees per year & Remarks \\
\hline Extension personnel & 2 & 135 & During March \\
Scouts & 12 & 1,000 & During April-May \\
Pesticide dealers & 10 & 2,578 & During March-April \\
Farmers & 9 & 4,500 & Two camps per district \\
$\quad$ District level & 105 & 21,000 & Five camps per block \\
Block level & 5,280 & 132,000 & Five camps per village \\
Village level & & & \\
\hline
\end{tabular}

Table 4. Insecticide use on cotton in Punjab during 2015-2018

\begin{tabular}{|c|c|c|c|c|c|}
\hline \multirow[b]{2}{*}{ Group of insecticides } & \multirow[b]{2}{*}{ Insecticides } & \multicolumn{4}{|c|}{ Total cost (INR) } \\
\hline & & 2015 & 2016 & 2017 & 2018 \\
\hline Botanical & Neem oil & $7,809,550$ & $23,560,250$ & $6,316,800$ & $13,424,760$ \\
\hline Organophosphorus & Acephate 75SP & $43,579,900$ & $2,286,900$ & 212,500 & 150,000 \\
\hline Organophosphorus & Monocrotophos 36SL & 15,750 & 0 & 210,000 & 114,000 \\
\hline Organophosphorus & Dimethoate $30 \mathrm{EC}$ & 643,750 & $9,075,000$ & $2,020,900$ & $2,239,240$ \\
\hline Organophosphorus & Ethion 50EC & $83,186,400$ & $72,474,400$ & $35,793,450$ & $34,866,500$ \\
\hline Organophosphorus & Triazophos 40EC & $205,450,000$ & $86,909,200$ & $44,894,800$ & $29,116,000$ \\
\hline Neonicotinoid & Imidacloprid $17.8 \mathrm{SL}$ & $44,381,600$ & $9,416,800$ & $11,709,900$ & $16,175,600$ \\
\hline Neonicotinoid & Thiamethoxam $25 \mathrm{WG}$ & $138,073,000$ & $33,266,000$ & $31,709,000$ & $31,944,000$ \\
\hline Neonicotinoid & Acetamiprid 20SP & $28,222,400$ & 524,800 & 210,000 & 175,000 \\
\hline Pyridine carboxamide & Flonicamid 50WG & $42,211,000$ & $60,989,500$ & $68,208,000$ & $78,331,000$ \\
\hline Tetronic acid derivatives & Spiromesifen 22.9SC & $372,913,200$ & $32,418,000$ & $20,797,200$ & $26,166,800$ \\
\hline Insect growth regulator & Pyriproxyfen 10EC & $8,969,000$ & $25,819,000$ & $40,064,750$ & $29,340,000$ \\
\hline Thiourea & Diafenthiuron 50WP & $169,226,000$ & $50,180,000$ & $65,272,500$ & $41,150,400$ \\
\hline \multicolumn{2}{|l|}{ Total } & $1,144,681,550$ & $406,919,850$ & $327,419,800$ & $303,193,300$ \\
\hline \multicolumn{2}{|c|}{ Reduction in insecticide use over that in 2015} & - & $737,761,700$ & $817,261,750$ & $841,488,250$ \\
\hline \multicolumn{2}{|c|}{$\begin{array}{l}\text { Per hectare savings in insecticide use compared to expenditure } \\
\text { incurred in } 2015\end{array}$} & - & 2,589 & 2,808 & 3,060 \\
\hline
\end{tabular}

Source: Department of Agriculture and Farmers' Welfare, Government of Punjab.

of whitefly populations, and feedback from extension functionaries and experts. In fields showing severe infestation of whiteflies, the gap between sprays of adulticides like diafenthiuron/flonicamid and nymphicides like pyriproxyfen/spiromesifen was curtailed to three days, instead of the earlier seven days. Under severe drought conditions, farmers were advocated to use flonicamid over diafenthiuron to protect the crop from phytotoxicity, though the latter option provided a greater kill. These mid-course modifications in strategy were passed on to the growers expeditiously through various communication media.

\section{An agroecosystem-wide integrated cotton whitefly management approach}

The above discussed measures considered all major aspects of whitefly management, thus providing a solution which may be narrowly termed as 'integrated whitefly management'. The spectrum of interventions, in fact, goes well beyond conventional IPM by including features of the cotton agroecosystem such as non-crop hosts, microenvironment influence of the cropping system, nutrition and abiotic stress. While the whitefly was successfully managed, Figure 1 clearly depicts the success achieved during 2016, 2017 and 2018 in terms of productivity. The increase in productivity is not a mere restoration of previous levels, but attainment of a new threshold - an alltime record of $756 \mathrm{~kg}$ lint/ha was achieved in Punjab in 2016 , in contrast to $196 \mathrm{~kg}$ lint/ha during 2015. In 2017 again, high productivity of $750 \mathrm{~kg}$ lint/ha and in 2018 , a record breaking yield of $778 \mathrm{~kg}$ lint/ha were achieved in the state. These figures from the Government of Punjab are based on actual arrivals in the market ${ }^{14}$.

The gains are best put in perspective by not just productivity, but also savings in pesticide costs. Table 4, which shows the expenditure by farmers on various pesticides in cotton-growing districts of Punjab, paints a clear picture of the impact of the whitefly campaign. These figures were painstakingly compiled from records of individual dealers by the functionaries of the Department of Agriculture and Farmers' Welfare, Government of Punjab (Sukhdev Singh Sidhu, pers. commun.). In 2016 and 2017, the use of insecticides like neonicotionoids (imidacloprid, thiamethoxam) and organophosphates (triazophos) was reduced to one-fourth of their level in 2015. 
The results were even more remarkable for acephate and acetamiprid, which reduced to less than $5 \%$ of its 2015 usage. All these broad-spectrum pesticides were the cause of resurgence of whiteflies due to indiscriminate killing of natural enemies ${ }^{9}$. The use of ethion was reduced because of its low effectiveness. Targeted green-chemistry insecticides belonging to different groups like insect growth regulator (pyriproxyfen) and pyridine carboxamide (flonicamid) showed justifiable increases. The adoption of IPM strategy resulted in reducing pesticide use in Punjab by INR 737.8 million (savings of INR 2589/ha for the cotton-growers) in 2016 over 2015 . The IPM campaign in 2017 resulted in still further reduction in pesticide use worth INR 817.3 million (savings INR 2808/ha), and in 2018 worth INR 841.5 million (savings of INR 3060/ha) over the consumption in 2015.

\section{Conclusion}

In a wider perspective, the region in question overlaps completely with the intensive agricultural hub of the country. Five successful decades of high-input agriculture has led to concerns about its impact on the environment and natural resource base. The present account of combating whitefly menace on cotton has this situation as a backdrop. A knowledge-intensive and multidisciplinary approach which leads to a dramatic reduction in chemical use along with unprecedented improvement in productivity should qualify as a model for future agricultural transitions.

1. van Lenteren, J. C. and Noldus, L. P. J. J., Whitefly-plant relationships: behavioral and ecological aspects. In Whitefly: Their Bionomics, Pest Status and Management (ed. Gerling, D.), Intercept, Andover, Hants, UK, 1990, pp. 47-89.

2. Vyskocilova, S., Tay, W. T., Brunschot, S. V., Susan, S. and Colvin, J., An integrative approach to discovering cryptic species within the Bemisia tabaci whitefly species complex. Sci. Rep., 2018, 8, 10886; doi:10.1038/s41598-018-29305-W.

3. Naveen, N. C., Chaubey, R., Kumar, D., Rebijith, K. B., Rajagopal, R., Subrahmanyam, B. and Subramanian, S., Insecticide resistance status in the whitefly, Bemisia tabaci genetic groups Asia-I, Asia-
II-1 and Asia-II-7 on the Indian subcontinent. Sci. Rep., 2017, 7, 40634; doi:10.1038/srep40634.

4. Gennadius, P., Disease of the tobacco plantations in the Trikonia. The aleurodid of tobacco. Ellen. Georgia, 1889, 5, 1-3.

5. Butter, N. S. and Vir, B. K., Response of whitefly, Bemisia tabaci Genn. to different cotton genotypes under glasshouse conditions. Indian J. Ent., 1991, 53, 115-119.

6. Aneja, A. K., Studies on the biology of cotton whitefly Bemisia tabaci (Gennadius) on American cotton, Gossypium hirsutum (Linnaeus). M Sc thesis, Punjab Agricultural University, Ludhiana, 2000 .

7. Byrne, D. N., Migration and dispersal by sweet potato whitefly, Bemisia tabaci. Agric. For. Meteorol., 1996, 97(4), 309-316.

8. Verma, S. and Bhattaacharya, A., Whitefly destroys 2/3rd of Punjab's cotton crop, 15 farmers commit suicide. Times of India, 8 October 2015; http://timesofindia.indiatimes.com/articleshow/49265083.cms? source $=$ contentofinterest\&utm medium $=$ text\&utm campaign $=$ cppst

9. Virk, J. S., Brar, K. S. and Sohi, A. S., Impact of insecticides on the resurgence of jassid and whitefly in cotton. Indian J. Ent., 2004, 66, 319-322.

10. Kumar, V. and Grewal, G. K., Relative toxicity of different insecticides to Bemisia tabaci (Gennadius) on cotton in Punjab. Pestic. Res. J., 2014, 26, 48-55.

11. Naranjo, S. E. and Ellsworth, P. C., Fifty years of the integrated control concept: moving the model and implementation forward in Arizona. Pest Mgmt. Sci., 2004, 65, 1267-1286.

12. Dhillon, B. S. and Sidhu, R. S., Successful management of whitefly incidence in cotton through joint efforts of farm experts and farmers. Prog. Fmg-Mont. J. Punjab Agric. Univ., 2016, 52, $5-7$.

13. Kumar, V. and Bhullar, H. S., Tips for successful management of whitefly in cotton. Prog. Fmg-Mont. J. Punjab Agric. Univ., 2017, 53, 14-15.

14. Anon., Agriculture at a Glance, Directorate of Agriculture and Farmers' Welfare, Mohali, Punjab, 2019, p. 20.

15. Anon., Strategy for management of whitefly in cotton. Report submitted by Punjab Agricultural University, Ludhiana to Government of Haryana, 2015, p. 17.

ACKNOWLEDGEMENTS. The whitefly management strategy owed greatly to the Interstate Consultative and Monitoring Committee for Whitefly Management in Cotton. Chairman of the Committee Dr B. S. Dhillon, Vice Chancellor, Punjab Agricultural University, Ludhiana provided valuable insights for the above account.

Received 11 May 2020; revised accepted 8 July 2020

doi: $10.18520 / \mathrm{cs} / \mathrm{v} 119 / \mathrm{i} 4 / 618-624$ 